\title{
Positive psychology cinemeducation: A review of Happy
}

Happy, a feature length documentary film directed by Roko Belic, 2011

\author{
Review by \\ Ryan M. Niemiec
}

\begin{abstract}
The documentary film, Happy, offers educators and practitioners a unique opportunity to provide a novel learning experience for students and clients. The film integrates meaningful stories and expert interviews with quality filmmaking to offer viewers knowledge, entertainment, and engagement. Cinematic elevation, the process by which a viewer observes virtuous behavior, feels physiological sensations of inspiration, and is consequently motivated to do good or to be a better person (e.g., copying the strengths of the film's characters) is particularly at play in Happy. Where there are gaps in the film's scope of the field of happiness, wellbeing, and positive psychology, suggestions are made for the viewer to overcome these and maximize the potential to derive benefit from the film.
\end{abstract}

Keywords: Happiness, character strengths, elevation, wellbeing, movies/films, cinemeducation, cinematherapy

\section{Introduction}

It has been said that happiness is less about the destination and more about the journey. When we look at research in positive psychology, the decades of happiness research prior to positive psychology's initiation in the late 1990s, and the millennia during which scholars, philosophers, theologians, and educators have written about the topic, we come to understand this truth in a deeper way. But what is this journey really about? What are the ingredients of a happy life that is well-lived?

A cinematic response to these questions is offered in the independent film, Happy, directed by Roko Belic, which takes a contemporary lens on happiness, integrating age-old wisdom, dynamic storytelling, beautiful cinematography, and interviews with leading scientists and the general public. The film offers wisdom from well-known figures in positive psychology, e.g., Mihaly Csikszentmihalyi, Richard Davidson, Ed Diener, Daniel Gilbert, and Sonja Lyubomirsky, as well as equally stellar researchers such as Tim Kasser and P. Read Montague. Tid-bits of happiness research abound and those new to positive psychology will be particularly fascinated by the country of Bhutan's establishment of a Gross National Happiness Index; Denmark as being the happiest country; and the frequently reported happiness pie chart, a heuristic that summarizes research noting that $40 \%$ of the variance of happiness, on average, is attributable to intentional activities people might engage in (Lyubomirsky, 2007). Then there are the lesser-known tid-bits the film offers, such as how the island of Okinawa, 
Japan, has a higher concentration of centenarians (those living to age 100 or more) than anywhere else in the world, or the finding that religious fundamentalists are less happy people.

It should be noted that Happy is among a stream of positive psychology documentaries that have recently emerged, including How Happy Can You Be? (2005), a Norwegian film that interviews similar figures (e.g., Diener, Lyubomirsky) along one woman's journey to discover the best strategies for boosting happiness; this film merges descriptive science and prescriptive messages accordingly. Similarly, the recent PBS documentary series, This Emotional Life (2010), hosted by Gilbert, also explores positive psychology themes with the intention of making the science more easily understood to viewers. While all three are on solid ground in educating the viewer, Happy is probably the most entertaining in its approach.

\section{Stories that educate}

What is most captivating in the film is not the empirical evidence that is shared; rather it is the stories, which bring the findings of positive psychology to life. Each story comes with an instructive message for the viewer, sometimes containing an emotional jolt. In addition, each story presents an opportunity for cinemeducation - which refers to the use of film for educational purposes - (Alexander \& Waxman, 2000) or cinematherapy (Berg-Cross, Jennings, \& Baruch, 1990; Wedding \& Niemiec, 2003) in that instructors and practitioners can use these segments as a springboard to build rapport, discuss relevant research/practices with their students/clients, and provide insights in a novel way. Here are a few of the standout stories and their educational message:

Melissa Moody: Story of a woman who was run over by a truck which crushed her face. This serious trauma led to 30 facial surgeries, her husband leaving her, total disability for nine-anda-half years, and subsequent recall of early sexual abuse she had repressed. Melissa became angry that she was still alive and began to contemplate suicide. The driving force that kept her persevering and hoping for a better tomorrow was the thought of wanting to be there for her children "today." That attitude helped her recover, find love again, and re-discover herself. She states she is happier, more grounded, more grateful, and more self-aware and connected to who she is because of the trauma that happened to her. She advises that happiness is a choice, which of course is a trite message that is true to the degree that some variance of our happiness depends on the activities we consciously engage in, but that amount of control varies from person to person. Melissa's segment is an opportunity for the educator to speak on this topic of intentional choice and happiness (Lyubomirsky, 2007) as well as the emerging literature on posttraumatic growth (Helgeson, Reynolds, \& Tomich, 2006; Tedeschi \& Calhoun, 2004).

Anne Bechsgaard: Anne's story revolves around her life transition to a co-housing facility in Denmark, which is a community of 20 families that share space, friendship, and support for one another. She describes how her finding this community for herself and her children to live in was nothing short of transformational. Anne's segment is an opportunity for educators to have conversations with students and clients about the value of community, social support, and positive relationships (Diener \& Seligman, 2002)

Roy Blanchard: Roy's story is set in the Louisiana bayou, in which he spends his time roving the swamps and celebrating with his family and neighbors over piles of crawfish he has captured. He explains how when he gets upset, he watches the birds and "listens to the stillness" of the bayou. Roy's segment is an opportunity for educators and practitioners to discuss the value of mindfulness (Bishop et al., 2004) - which Roy shows at both the good times 
and the difficult times - as well as to show character strengths, such as appreciation of beauty, love, and teamwork, in action.

\section{An opportunity for cinematic elevation}

There's another story that is so directly inspirational that, similar to the stories mentioned earlier, it may elicit the emotion of elevation in the viewer. 'Elevation' is a recently coined term that refers to the experience of observing an act of moral goodness that leads to physiologic sensations of tingling in the body and warming in the chest, and then motivates the observer to do good or to be a better person (Haidt, 2003). The application of this emotion to the film-going experience, in which a movie character's expression of virtue and strength of character elicits the corresponding physiology as well as a motivation to emulate the character or to help others, is cinematic elevation (Niemiec \& Wedding, 2008).

One segment of Happy concerns Michael Pritchard, a comedian/educator who speaks to students in high schools. He intersperses age-appropriate humor with poignant messages to help students improve their lives, treat each other more altruistically, and build a stronger school community. Pritchard repeatedly asks students to come to the front of the gym and - in front of the school - share their fears and express their emotions about what it is like to be picked on, bullied, or viewed as different. Remarkably, no doubt due to Pritchard's charisma, students come forth. They share deeply and they cry. With clever timing and social intelligence, Pritchard enthusiastically praises each child for their courage in standing up in front of the school. Interestingly, and perhaps unknown to Pritchard, research indicates that labelling acts of courage has been found to be an effective approach for boosting this character strength (Hannah, Sweeney, \& Lester, 2007). The students in the audience cheer wildly for the brave students, even hoisting one of them on their shoulders as they leave the gym. A viewer would be hard-pressed not to feel motivated to be more prosocial after viewing this scene.

Considering each of these stories, it is in this vein that the film shines and Belic - just 40 years old - proves himself again to be a young master at telling stories through the medium of film. Previously, he told the story of Paul Pena in Genghis Blues (1999) with great success. That film was his directorial debut and an Academy Award nominee for Best Documentary Feature. Pena, a blind, depressed, San Francisco blues singer, taught himself the rare art of Tuvan throat-singing after first hearing it on a Russian radio broadcast. Belic and his film crew decided to follow Pena to the remote country of Mongolia to film his performance in a throatsinging competition. The viewer cannot help but feel inspired by Pena's charisma, courage, and perseverance in overcoming various physical and psychological obstacles, and his ability to forge connections with a culture (that he cannot see) that is virtually unknown to Western society. This film is likely to cinematically elevate viewers to follow their own passion no matter how obscure, to stay true to their values and strengths, to practice perseverance and bravery, and to live life lightheartedly with zest and playfulness.

\section{Happy as a tool for practitioners}

The literature on happiness and wellbeing has established a number of links and correlations between happiness, wellbeing, and those outcomes that people care about most. When I am asked to name what I perceive to be the clinically relevant areas that are most impactful for practitioners and educators, I cite three general areas:

1) Find ways to help your client tap deeper into meaning (Kashdan \& Steger, 2007; Steger, Oishi, \& Kashdan, 2009). 
2) Help clients to prioritize the development of positive, close relationships (Diener \& Seligman, 2002; Gable, Reis, Impett, \& Asher, 2004; Peterson, 2006).

3) Work with clients to discover, explore, and apply their character strengths in order to engage fully in their life, work, relationships, and goals (Among children and youth: Madden, Green, \& Grant, 2011; Park \& Peterson, 2006a; Park \& Peterson, 2006b. Among adults: Linley, Nielsen, Gillett, \& Biswas-Diener, 2010; LittmanOvadia \& Davidovitch, 2010; Littman-Ovadia \& Steger, 2010; Seligman, Steen, Park, \& Peterson, 2005).

Happy directly taps the first two pathways in a stellar form, but the viewer is left to work for the third. While strengths like gratitude and kindness receive brief attention, it is surprising that the words "strengths" or "character strengths" are not mentioned even once in the film. This is a misstep, considering character strengths have been viewed by many as the backbone of positive psychology, the core ingredients or pathways to happiness and to wellbeing (Seligman, 2002; Park, Peterson, \& Seligman, 2004). One of the largest projects in positive psychology to date was the creation of the VIA Classification of 24 character strengths, which is viewed as a common language for describing one's best qualities (Peterson \& Seligman, 2004). Several studies have linked the practice of using one's highest character strengths - often called signature strengths - with greater levels of happiness/wellbeing (Linley et al., 2010; Mitchell, Stanimirovic, Klein, \& Vella-Brodrick, 2009; Mongrain \& Anselmo, 2009; Rust, Diessner, \& Reade, 2009; Peterson \& Peterson, 2009; Seligman et al., 2005). This omission notwithstanding, the film is dynamic enough that the educator instructing students, the practitioner guiding a client, and the savvy viewer can use the film as an opportunity for learning about strengths, albeit indirectly.

To this end, my suggestion is to practice strengths-spotting (Linley, 2008), in which the viewer looks for the character strengths that emerge in the individuals interviewed in the film. A student might have fun with the task of attempting to spot each of the 24 VIA character strengths during the 75 minutes. A related approach is to review the stories mentioned earlier and the others in the film and practice spotting the character strengths of each individual and connecting the strength with particular actions and outcomes. Each story is a clear portrayal of character strengths in action. These initial exercises can act as a springboard for the student or client to then turn their strength "goggles" inward and identify, explore, and embrace their own strengths and link them with personal goals.

\section{Debunking misconceptions}

Belic is effective and instructive in using the medium of film to bring benefit to the field of positive psychology. Often, positive psychology suffers from mistaken identity in which hasty conclusions are made about the field being nothing but "happiology," that it is unscientific and soft, or that its approach is simply "old wine in a new bottle." Belic helps to debunk such misconceptions in a number of cinematic ways. After the film opens with a flurry of happiness images along with energetic, non-diegetic sound, the camera unexpectedly turns to a Kolkata slum in India. The viewer is introduced to Manoj Singh, a poor rickshaw driver who works grueling hours with unfavorable treatment by customers for pay that only sometimes is enough to buy food for his family, yet Manoj's face, attitude, and behavior emanate a genuine happiness. He is a role model to the world. The narrator then shares that Manoj scores as high as the average American on happiness measures (measured by one of the most utilized happiness instruments in the world, the Satisfaction with Life Scale: Diener, Emmons, Larsen, \& Griffin,1985). Manoj explains that seeing the joy on his child's face when he returns from 
work, feeling gratitude for what he does have, and connecting with his neighbors and friends are some of the ingredients of his happiness.

This segment is a foreshadowing of an important message: An authentic happiness can be found in anyone, whether those who are the most poor (Indian rickshaw driver), those who are the most remote geographically (the bushmen of the Kalahari Desert in Namibia), or those separated from the mainstream (living in the swamps of Louisiana). Belic furthers this message with more contrasts. Rather than simply showing people in a one-dimensional caricature of happiness, he shows the nuances and deep suffering of some, and the balance and happiness that is found among the vicissitudes of life, e.g., exhibiting both the "workaholic" quality of Japan's culture as well as the community engagement and social cooperation found on Japan's island of Okinawa. Meanwhile, Belic is cognizant of the viewer's emotions and works to juxtapose stories that are likely to induce sadness and empathy (e.g., an example of a man who works himself to death) followed by a story likely to motivate the viewer (e.g., an inspiring story of the country of Bhutan).

While Happy should not be seen as an all-inclusive coverage of happiness, it is a good primer, and will be of most interest to professors and practitioners interested in helping their students and clients garner a deeper understanding of happiness. Students and clients, in turn, will experience an education on happiness that is entertaining and engaging.

I believe that positive psychology's substantive themes, and often inspiring findings, mixed in with the entertaining medium of film is a win-win learning platform, especially in terms of educating students, assisting clients, and connecting communities together. My colleague, Danny Wedding, and I believe so strongly in this that we wrote a book on the topic (Niemiec \& Wedding, 2008), and no doubt Belic's film will make it into the next edition because it certainly meets the criteria for a positive psychology film (Niemiec, 2007). In the end, Belic has provided viewers with a great vehicle for infusing joy into their journey of positive psychology cinemeducation.

\section{Author}

Ryan M. Niemiec

VIA Institute on Character

ryan@viacharacter.org

\section{Publishing Timeline}

Received 4 September 2011

Accepted 4 September 2011

Published 17 October 2011

\section{References}

Alexander, M., \& Waxman, D. (2000). Cinemeducation: Teaching family systems through the movies. Families, Systems, E Health, 18(4), 455-466.

Berg-Cross, L., Jennings, P., \& Baruch, R. (1990). Cinematherapy: Theory and application. Psychotherapy in Private Practice, 8, 135-156.

Bishop, S. R., Lau, M., Shapiro, S., Carlson, L., Anderson, N. D., Carmody, J., Segal, Z. V., Abbey, S., Speca, M., Velting, D., \& Devins, G. (2004). Mindfulness: A proposed operational definition. Clinical Psychology: Science and Practice, 11(3), 230-241. http://dx.doi.org/10.1093/clipsy.bph077

Diener, E., Emmons, R. A., Larsen, R. J., \& Griffin, S. (1985). The satisfaction with life scale. Journal of Personality Assessment, 49, 71-75. 
Diener, E., \& Seligman, M. E. P. (2002). Very happy people. Psychological Science, 13, 81-84. http://dx.doi.org/10.1111/1467-9280.00415

Gable, S. L., Reis, H. T., Impett, E. A., \& Asher, E. R. (2004). What do you do when things go right? The intrapersonal and interpersonal benefits of sharing positive events. Journal of Personality and Social Psychology, 87, 228-245. http://dx.doi.org/10.1037/0022-3514.87.2.228

Haidt, J. (2003). Elevation and the positive psychology of morality. In C. L. M. Keyes \& J. Haidt (Eds.), Flourishing: Positive psychology and the life well-lived (pp. 275-289). Washington, D.C.: American Psychological Association. http://dx.doi.org/10.1037/10594-012

Hannah, S. T., Sweeney, P. J., \& Lester, P. B. (2007). Toward a courageous mindset: The subjective act and experience of courage. Journal of Positive Psychology, 2(2), 129-135.

Helgeson, V. S., Reynolds, K. A., \& Tomich, P. L. (2006). A meta-analytic review of benefit finding and growth. Journal of Consulting and Clinical Psychology, 74(5), 797-816. http://dx.doi.org/10.1037/0022006X.74.5.797

Kashdan, T. B. \& Steger, M. F. (2007). Curiosity and pathways to well-being and meaning in life: Traits, states, and everyday behaviors. Motivation and Emotion, 31, 159-173. http://dx.doi.org/10.1007/s11031$\underline{007-9068-7}$

Linley, A. (2008). Average to A+: Realising strengths in yourself and others. Coventry, UK: CAPP Press.

Linley, P. A., Nielsen, K. M., Gillett, R., \& Biswas-Diener, R. (2010). Using signature strengths in pursuit of goals: Effects on goal progress, need satisfaction, and well-being, and implications for coaching psychologists. International Coaching Psychology Review, 5(1), 6-15.

Littman-Ovadia, H., \& Davidovitch, N. (2010). Effects of congruence and character-strength deployment on work adjustment and well-being. International Journal of Business and Social Science, 1(3), $138-146$.

Littman-Ovadia, H., \& Steger, M. (2010). Character strengths and well-being among volunteers and employees: Toward an integrative model. Journal of Positive Psychology, 5(6), 419-430.

Lyubomirsky, S. (2007). The how of happiness: A scientific approach to getting the life you want. New York: Penguin.

Madden, W., Green, S., \& Grant, A. M. (2011). A pilot study evaluating strengths-based coaching for primary school students: Enhancing engagement and hope. International Coaching Psychology Review, 6(1), 71-83.

Mitchell, J., Stanimirovic, R., Klein, B., \& Vella-Brodrick, D. (2009). A randomised controlled trial of a self-guided internet intervention promoting well-being. Computers in Human Behavior, 25, 749-760.

Mongrain, M., \& Anselmo, T. (2009). Promise of positive interventions: Replication of Seligman et al., 2005. Paper presented at American Psychological Association conference on August 6, 2009.

Niemiec, R. M. (2007, September 19). What is a positive psychology film? [Review of the motion picture The pursuit of happyness]. PsycCRITIQUES - Contemporary Psychology: APA Review of Books, 52 (No. 38). Article 18. Retrieved December 15, 2007.

Niemiec, R. M., \& Wedding, D. (2008). Positive psychology at the movies: Using films to build virtues and character strengths. Cambridge, MA: Hogrefe.

Park, N., \& Peterson, C. (2006a). Character strengths and happiness among young children: Content analysis of parental descriptions. Journal of Happiness Studies, 7, 323-341. http://dx.doi.org/10.1007/s10902-005-3648-6

Park, N., \& Peterson, C. (2006b). Moral competence and character strengths among adolescents: The development and validation of the Values in Action Inventory of Strengths for Youth. Journal of Adolescence, 29, 891-905.

Park, N., Peterson, C., \& Seligman, M. E. P. (2004). Strengths of character and well-being. Journal of Social $\mathcal{E}$ Clinical Psychology, 23, 603-619.

Peterson, C. (2006). Positive psychology primer (pp. 249-274). New York: Oxford University Press.

Peterson, C., \& Seligman, M. E. P. (2004). Character strengths and virtues: A handbook and classification. New York: Oxford University Press.

Peterson, T. D., \& Peterson, E. W. (2009). Stemming the tide of law student depression: What law schools need to learn from the science of positive psychology. Yale Journal of Health Policy, Law, and Ethics, 9(2), 358-359. 
Rust, T., Diessner, R., \& Reade, L. (2009). Strengths only or strengths and relative weaknesses? A preliminary study. Journal of Psychology, 143(5), 465-476.

Seligman, M. E. P. (2002). Authentic happiness: Using the new positive psychology to realize your potential for lasting fulfillment. New York: Free Press.

Seligman, M. E. P., Steen, T. A., Park, N., \& Peterson, C. (2005). Positive psychology progress: Empirical validation of interventions. American Psychologist, 60, 410-421.

Steger, M. F., Oishi, S., \& Kashdan, T. B. (2009). Meaning in life across the life span: Levels and correlates of meaning in life from emerging adulthood to older adulthood. Journal of Positive Psychology, 4, 4352.

Tedeschi, R. G., \& Calhoun, L. G. (2004). Posttraumatic growth: Conceptual foundations and empirical evidence. Psychological Inquiry, 15(1), 1-18. http://dx.doi.org/10.1207/s15327965pli1501_01

Wedding, D., \& Niemiec, R. M. (2003). The clinical use of films in psychotherapy. Journal of Clinical Psychology, 59(2), 207-216. http://dx.doi.org/10.1002/jclp.10142 